Otrusinova, M., Kulleova, A. (2019). Liquidity Values in Municipal Accounting in the Czech Republic.

Journal of Competitiveness, 11(1), 84-98. https://doi.org/10.7441/joc.2019.01.06

\title{
LIQUIDITY VALUES IN MUNICIPAL ACCOUNTING IN THE CZECH REPUBLIC
}

- Milana Otrusinova, Alena Kulleova

\begin{abstract}
The aim of this paper is to present the results of a study which analyzes the use of liquidity management among municipalities within the Czech Republic. A research carried out by the Faculty of Management and Economics of TBU in Zlín found that the use of liquidity management in Czech cities is still relatively low. Two basic data collection methods were applied: the use of accounting information from the public database (260 municipalities) and a questionnaire survey implemented in the form of controlled interviews (167 respondents). Applying the accounting data database, we sought to determine whether the recommended values of individual liquidity ratios are also valid in the public sector, specifically among municipalities. Based on the data analysis, we ascertained that most liquidity values of municipalities indicate higher values than those stated as recommended for the private sector, but based on this statistical evaluation, it is not possible as of yet to positively confirm this hypothesis at the significance level 0.05. The results of the study showed that municipalities use liquidity management within a limited scope. Non-profit organizations are recommended to control their liquidity according to general rules, whereas for municipalities it is most advantageous to use the quick ratio and cash position ratio. Each municipality can therefore determine the mutual relationship between components of short-term assets and short-term liabilities according to their own conditions and limitations, e.g. when handling flow transfers, money in funds, or tax income and expenses.
\end{abstract}

Keywords: liquidity, public sector, public management, municipalities, accounting, performance, competitiveness, financial management

JEL Classification: $M 41, H 21$

Received: June, 2018

1st Revision: January, 2019

Accepted: February, 2019

\section{INTRODUCTION}

The issue of performance measurement and management of organizations has been prominent for many years. Corporations have generally been forced to function with an effective, efficient, flexible and lean operation. In recent years, this trend has also moved into the area of public administration. Some municipalities or regions have attempted to introduce tools and concepts from which they expect a positive response. Public administration includes a number of areas and types of organizations, also depending on the geographical or governmental organization. 
In the Czech Republic, Nemec (2016) has engaged with the efficiency of public administration. His case studies demonstrate major problems associated with measuring and managing performance. The changes in the possibilities of measuring the performance of public organizations has also contributed to the reform of public finances, which established an accrual basis of public finance accounting. (Vodáková, 2014)

Ensuring liquidity is one of the primary tasks of financial management and competitiveness of every organization, and municipalities are no exception, including public administration institutions and in the public sector. One may surmise that the assessment of liquidity and its sensible use may be one of the factors leading to an increase in the financial performance of municipalities. However, there still exists a lack of proof that municipalities in the Czech Republic are sufficiently exploiting the potential of liquidity ratios. This paper aims to gauge the awareness of municipal managers regarding liquidity management and whether the recommended values of individual liquidity ratios are valid also in municipalities. The sections that follow consist of a theoretical background and further develop scientific questions. The next part presents the methodology used in the article. The fourth part is concluded by a discussion about the results achieved along with the methodological constraints of the paper.

\section{LITERATURE REVIEW}

The increases in a company's performance and transparency is listed in the management top-priority list. According to Mohelská \& Sokolová (2017), the concept of transparency has been one of the most discussed topics within good governance over the last 20 years and therefore it attracts interest for academic study. Since the late 1980s, a variety of approaches, termed New Public Management, have been considered international best practice (Wynne, 2012). One aspect of the New Public Management concept should be the role of accounting and financial analysis and it represents a strategy oriented on increasing efficiency. Astrini (2015) presents a study on how a local government should develop its performance measurement indicator. According to Androniceanu \& Popescu (2017), in general, in recent decades, almost all the countries in the world have adopted legislative measures to develop public management in various spheres of public sector performance. It has been argued that performance information can assist the managers of firms in making more informed decisions regarding control of the process (Romolini et al., 2015, Rauscher \& Wheeler, 2012, Woronkowicz, 2016). Efficient working capital management allows municipalities to reduce their holdings of current assets, with the cash inflows available to reduce debts.

One of the options for increasing the efficiency of municipalities is financial analysis, which usually leads to practical use of knowledge, thus forming a basis for an objective definition of relevant conditions for future capital appreciation of municipalities. (Papcunová, 2013).

Liquidity management applies accounting techniques in order to ascertain the need for the cash necessary for repaying financial liabilities. Means to assess liquidity using ratios vary among individual authors and interpretations, with various modifications to these methods also introduced (Knápková et al., 2017, Kraftová, 2002, Otrusinova \& Kubíčková, 2011). The liquidity value expresses the ability of the organization to pay off its obligations. This ratio measures what 
can be paid with what must be paid. Liquidity expresses the ability of the organization to generate finances to reduce its short-term liabilities. Monitoring the development of the value of the liquidity ratio is very important, as an advantageous ratio can eliminate opportunity costs from unused current assets, resulting in a decrease in economic efficiency. Regular liquidity management may prevent the late payment of liabilities; it thus enables regulation of the rate of flow of funds and ensures flexibility of short-term funds.

To ascertain liquidity, several calculations are applied, as several types of liquidity exist, i.e. the current ratio, quick ratio and cash position ratio (immediate liquidity). The recommended value is determined by the sector and specific degree of the liquidity ratio in a range oscillating around the value of 1 . The current ratio is considered a means applicable for paying off liabilities using all items of current assets, the quick ratio from current assets excludes at least the liquid component, which is formed of inventories and possibly bad debts. The strictest indicator then is the cash position ratio, which uses only short-term financial assets for calculation.

Municipal companies, just like business entities, may use the cash position, quick or current ratio. Which one of them they use depends on the facts of whether and in what measure they have inventories and receivables available. The total (current) ratio measures the ability of municipalities to cover their short-term liabilities from current assets, which means the ability of municipalities to cover their liabilities if all current assets were to be converted to cash in the given moment. It is used by the Ministry of Finance of the CR as one of the indicators for monitoring the municipality (SIMU indicator). The aim of monitoring is to lead municipalities towards greater prudence in the management of entrusted public funds. The adequate amount of this indicator is above 1, but a very high value proves unfavourable for municipalities. This means that the municipality needlessly retains many current assets, which could be used for its development. Municipalities having a value in the interval $<0.1>$, i.e. the value of current assets is not higher than short-term liabilities, are deemed risky (Kraftová, 2002, Otrusinova \& Kubíčková, 2011).

Liquidity management with debt management and balancing revenues and spending are basic elements of fiscal management of all governments (Hansen et al., 2014, Schwert, 2017). Ensure its liquidity is developed in the area of the functioning, forecasting and cash planning funds from the Federal budget and its management. Budget accounts liquidity management is secured by a strict legislative control, allowing in cases of lack of funds borrowing in the credit market to cover all necessary spending. By Dittrichova (2009), asset management services of municipalities are designed for long-term investments. Municipalities' free funds are invested according to the individually established guidelines, performance and risk objectives, liquidity and currency requirements and regulatory concerns (Lagos \& Rocheteau, 2009; Drew \& Campbell, 2016). Public finances require improvements, especially in the area of turnover and transparency of the budget funds, their turnover acceleration and exploitation efficiency. Collignon (2012) defines some requirements ensuring compliance of fiscal policy with the budget constraint in the context of Europe's fiscal policy rules. According to the author, European public debt is sustainable in this point, but questions about long-run liquidity requirements remain unresolved. Defaulting in respect the budget constant condition could effect confidence in the markets about the solvency of governments and reduce the liquidity needed for refinancing new or maturing debt. The rising default risk due to a liquidity crisis may force a government to implement changes in 
policy even if it is still solvent and debt is sustainable. A liquidity crisis could become a solvency crisis. The topics are addressed in publications by many authors such as Checherita-Westphal et al. (2016), Chovancova \& Hudcovsky (2016), Becerra Alonso et al. (2016) and YU-Thompson et al. (2015).

Municipalities and non-profit organizations are important part of general social policy in Czech economy. Thanks to them, important targets in education, in healthcare, and many other socially key areas are realized. By Janoušková \& Sobotovičová (2017), the issue of fiscal decentralization in the context of the autonomy of local self-governments is still current. Considering efficiency of municipalities, should be remembered that from the public finance perspective, the way the public is important management uses resources of these organization as well as if it is used in the most effective way. The municipalities efficiency should be considered in the context of the risk. This issue of non-profit or municipalities financial health is based on several studies, for example Prentice (2016) and Rosen \& Sappington (2016) explore the organizational and environmental factors that affect non-profit financial health. Szymanska \& Jegers (2016) theoretically describe social enterprises taking into consideration their main aims and they point out the direction which social enterprises should follow in order to obtain the highest value of their objective functions. Upadhyay et al. (2015) studied the relationship between the non-profit entity profitability and cash tied in operational activity. Rauscher \& Wheeler (2012) examine the relationship between the non-profit entities profitability and their performance at managing accounts payable. Some authors claim that non-profit finance and its managerial decisions in them are not different from for-profit business decisions (Jegers, 2011; Michalski, 2016; Grizzle et al., 2015, Gavurova \& Korony, 2016).

\section{METHODOLOGY}

This section describes research methodology - data collection, the process of designing and implementing and questionnaire survey. Furthermore, it specifies the scientific methods used to answer the research questions.

Data collection methods, the research implementation process and identification of the researched sample.

On the basis of the critical literary review, the two questions were posed in the introduction to the solution:

RQ1: Do municipalities in the CR utilize liquidity analysis in financial management?

RQ2: What is the information value of liquidity values among municipalities in the CR?

The research was performed in the year 2016. In the framework of research, two basic data collection methods were applied - the use of accounting information from the public database "Monitor" (Monitor, 2016) and the method of questionnaire survey implemented in the form of controlled interviews.

For the purposes of empirical analysis, there were used aggregate data sourced from the Ministry of Finance of the Czech Republic. In light of the nature of question RQ1, the method of questionnaire surveys was selected in the form of controlled interviews. This part of the research was implemented in September 2017 at workshops in Prague, Brno and Ostrava. The mayors 
and accountants of municipalities were mainly addressed. A total of 167 respondents took part (mayors and accountants), who responded to the questions about the liquidity values, the recommended values of liquidity ratios and applying the liquidity management.

The question RQ2 was answered based on financial data gained by means of financial statements of municipalities, which are available in the database "Monitor". Municipalities were tested with a population in a range of 5,001 - 50,000. From the total number of around 6,246 municipalities in the CR, municipalities in the analysed population range represent around $4 \%$ of all municipalities, most of which have the status of a town. Most municipalities are smaller, only 21 municipalities are larger in relation to population. (Czech Statistical Office, 2016). This range was selected due to comparable size of municipalities, and similar management of municipal funds was expected. For the analysis, a total of 130 randomly selected municipalities were used, 10 from each region. The values of all three liquidity ratios were calculated. For the comparison, there were tested municipalities with a population of up to 5,000, a total of 130 randomly selected municipalities were used, 10 from each region. In total, 260 municipalities were tested.

The next part of the paper examines whether recommended liquidity values are also the same for municipalities. Based on the research questions, a null hypothesis was determined. To test the hypothesis, the Chi-square test was applied. For statistical evaluation, the following hypotheses were determined:

H0: The recommended values of individual liquidity ratios for the business environment are also suitable and applicable for assessing liquidity among municipalities

In contrast, an alternative hypothesis that rejects the null hypothesis was determined as follows:

H1: Liquidity values among municipalities are higher than recommended

\section{EMPIRICAL RESULTS AND DISCUSSION}

\subsection{Use of the liquidity analysis for municipalities}

From the questionnaire survey it was ascertained that only around $6 \%$ of the analysed municipalities applied the liquidity analysis regularly and sensibly.

The following table (Tab. 1) illustrates the respondents' answers to the following questions:

1. Do you know the liquidity values of your municipality?

2. Do you know the recommended values of liquidity ratios?

3. Do you regularly perform the analysis of liquidity values?

Tab. 1 - Respondents' answers to the questions of interviews. Source: own

\begin{tabular}{|l|l|l|l|}
\hline Question & Yes & No & Partly \\
\hline 1 & $40.7 \%$ & $26.9 \%$ & $32.4 \%$ \\
\hline 2 & $23.3 \%$ & $28.7 \%$ & $48.0 \%$ \\
\hline 3 & $6.5 \%$ & $14.4 \%$ & $79.1 \%$ \\
\hline
\end{tabular}


According to the results of controlled interviews, the use of liquidity among all municipalities is chiefly perceived as a monitoring indicator for the needs of the Czech Ministry of Finance, in the framework of SIMU indicators. In accordance with this method, around 55\% of respondents considered total liquidity, i.e. current liquidity, as the more advantageous type of liquidity. Only one of the surveyed municipalities applies values of all three basic liquidity ratios in the framework of a regularly performed financial analysis, and the accountant knows these values from the previous year. Values of the current ratio were known to $52 \%$ of respondents and $34 \%$ of the surveyed municipalities are sure that they have liquidity higher than 1 , however, they do not know precise values. Most municipal representatives agree that they do not have problems with liquidity, so they do not need to analyse regularly all ratios of liquidity degrees. More frequently they apply cash flow management among individual sources of financing, mainly projects. Regarding the question focused on recommended liquidity values, $39 \%$ of respondents agreed that they should oscillate around the value of 1 . Most respondents (52\%) stated that the MF CR considers the value lower than 1 risky.

\subsection{Liquidity values among municipalities in the $\mathrm{CR}$}

For this analysis, data was applied from a group of 130 tested financial statements from the publicly available database. In the Czech Republic, there are 13 local self-governing units (regions). The regions are: South Bohemian, South Moravian, Karlovy Vary, Hradec Králové, Liberec, Moravian-Silesian, Olomouc, Pardubice, Pilsen, Central Bohemian, Ústí nad Labem, Zlín and Vysočina. On the tested sample of municipalities with a population in a range of 5,001 - 50,000, the values of current, quick and cash value ratios were assessed according to the status to 31 December 2016. This range was selected because of a comparable size of municipalities, and a similar management of municipal funds was expected. In the selection, there were always $10 \mathrm{mu}-$ nicipalities included from each region. For each of the 120 municipalities, the average, median, range and standard deviation were statistically assessed.

\section{Values of the current ratio}

Values of the current ratio (ratio of total current assets and short-term liabilities) in most tested municipalities fluctuate within the recommended interval (1.5 -2.5). For 14 municipalities only, a value lower than 1.5 was calculated. A critical value of the current ratio according to the Ministry of Finance is the value 1, four municipalities (3\%) reported this lower value to the closing day of 2016; these municipalities were Turnov, Ústí nad Orlicí, Kadaň and Rumburk. Eighty analyzed municipalities $(66 \%)$ indicate a current ratio value higher than recommended. A high value for the current ratio is given by the fact that most municipalities have several times lower short-term liabilities than current assets. This often forms a high amount of estimated active amounts, especially from transfers, which are caused by the specifics of financing municipalities. Such high values of estimated items appear less often among businesses. A major part by short-term liabilities is formed of short-term advances received (again frequently from transfers), the remainder is formed by current liabilities towards suppliers, employees and income tax. 


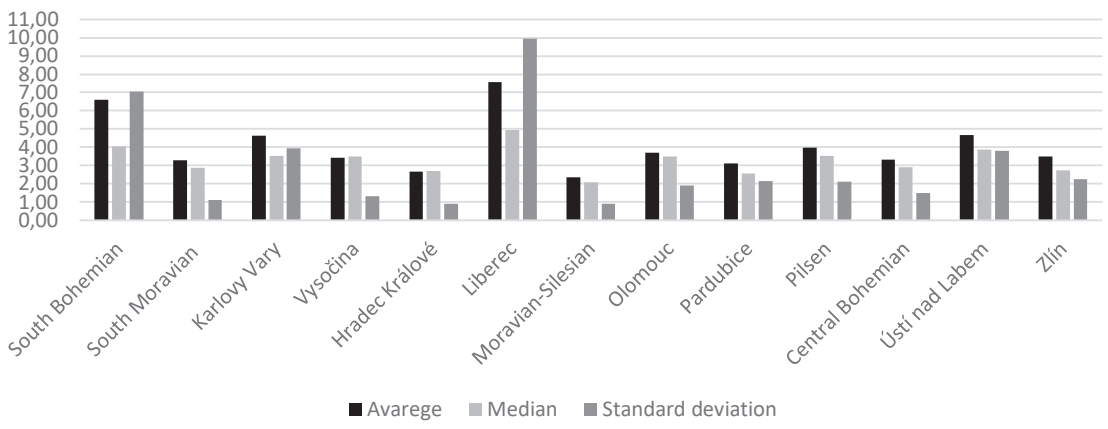

Fig. 1 - Values of the current ratio among regions in the CR. Source: own

\section{The quick ratio values}

Excluded from current assets when calculating the quick ratio, it is the least liquid item, i.e. inventories. To calculate the quick ratio, the amount of inventories and amount of accrued expenses are deducted from current assets. This is because funds are kept in inventories, and in the balance sheets of municipalities, in current assets and liabilities, these, as opposed to businesses, also indicate items of accruals and deferrals. To calculate the quick ratio values presented in this paper, items of accrued expenses and deferred revenue are eliminated from the numerator and denominator because it does not concern assets convertible to cash position funds or liabilities. The quick ratio values for most municipalities differ just very slightly from the value of the current ratio, since the value of inventories is mostly low among municipalities. In the monitored sample, only 11 municipalities indicate a quick ratio value in a recommended value, all the rest $(91 \%)$ indicate higher values.

\section{Immediate liquidity (the cash position ratio)}

Immediate liquidity among most selected municipalities (98, i.e. $82 \%)$ was higher than the value 1 , from which it clearly emerges that the analyzed municipalities have enough of the most liquid forms of funds, i.e. on bank accounts and in cash, so they can cover all short-term liabilities without problems. This analysis confirmed the result of controlled interviews that most municipalities have no problem with liquidity. Municipalities to the closing day generally have a sufficient amount of the most liquid forms of funds, 14 municipalities indicate a value higher than 5 (of these, Česka Lípa indicates a value of the cash position ratio of 34.59), only 1 analyzed municipality (Jablonec nad Nisou) achieves a value lower than 0.2 . The reason for the above-average values of the cash position ratio may be budgetary rules in affiliation with cash base management of budgets of Local Government Units in the CR, where it is necessary to financially settle most liabilities in the financial year. 


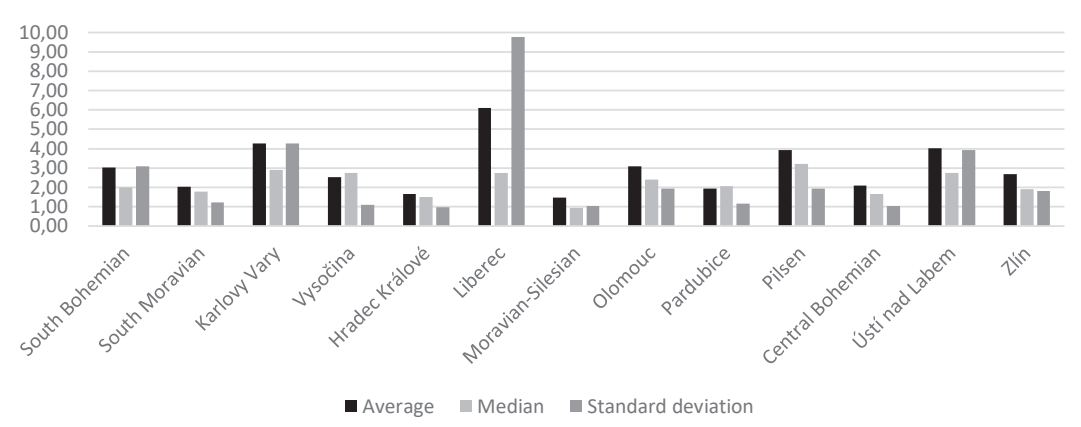

Fig. 2 - Values of the cash position ratio among regions in the CR. Source: own

\section{Statistical assessment}

In this part of the paper, we analyze the statistical evaluation of calculated values of the test data sample with the help of the level of the central tendency and range. It was revealed that most performed calculations of liquidity values came out with higher values than those stated as recommended values. Can we generalize this conclusion for all municipalities?

As statistical evaluation, for each region we calculated the mean value presented by the value "average", as well as the midpoint, presented by the value "median". To assess the distribution of midpoints, the levels of range and standard deviations were calculated. To express the level of uncertainty of statistical evaluation, the value of the standard error of the mean value was applied, which indicates how trustworthy the mean value is.

Tab. 2 - The average value of liquidity of municipalities with a population in a range of 5,001 - 50,000. Source: own

\begin{tabular}{|l|l|l|l|}
\hline Liquidity & current ratio & quick ratio & cash position ratio \\
\hline Average & 4.07 & 4.68 & 2.99 \\
\hline Median & 3.23 & 3.69 & 2.20 \\
\hline Range & 17.76305 & 20.61806 & 13.61573 \\
\hline Standard deviation & 4.214623 & 4.540711 & 3.68995 \\
\hline Standard error of the mean value & 0.3847 & 0.4145 & 0.3368 \\
\hline
\end{tabular}

We can state that the average value of the current ratio of municipalities with a population in a range of 5,001 - 50,000 in the Czech Republic is 4.07, the median is 3.23, the standard deviation is 4.214 and the standard error is 0.3847 . It is similar for the quick ratio and cash position ratio. The median and average indicate higher values than recommended; on average in the tested sample, municipalities have sufficient liquid funds to pay their short-term liabilities. Standard deviations indicate relatively higher values, which proves that in the tested sample, there are high differences in calculated values, thus it is not definite that all municipalities have no problem with liquidity. The analysis reveals that in the accounting of municipalities, significant differences exist for indicated values of current assets and liabilities. The standard error of mean values is relatively low, so it is possible to consider the mean value as probably average. 
Tab. 3 - The average value of liquidity of municipalities with a population lower than 5,000.

Source: own

\begin{tabular}{|l|l|l|l|}
\hline Liquidity & current ratio & quick ratio & cash position ratio \\
\hline Average & 8.09 & 9.52 & 6.19 \\
\hline Median & 4.54 & 5.42 & 3.45 \\
\hline Range & 112.5154 & 148.3382 & 49.0611 \\
\hline Standard deviation & 10.60733 & 12.17942 & 7.004363 \\
\hline
\end{tabular}

In Table 3, it is evident that the average value of the current ratio, quick ratio and cash position ratio of municipalities with a population lower than 5,000 in the Czech Republic are higher among these municipalities than recommended. It is not significant. If the mean is between 6 to 10 and the standard deviation is above 10 , the mean cannot be compared to other data.

The zero and alternative hypotheses were determined, and it was statistically examined whether it is possible to express for the alpha significance level $=0.05$ the demonstrable conclusion that liquidity values are higher among municipalities than recommended. In order to verify the hypothesis, a statistical test was calculated using the null hypothesis - Chi-squared test with p-value, which was conducted at the importance level of $5 \%$. We can state that at the selected significance level, it is not possible to accept the alternative hypothesis, and the results are not significant $(\mathrm{p}=0.053$, Chi-square $=0.706)$. It is not enough to reject the zero hypothesis that the recommended values of individual liquidity ratios for the business environment are suitable and applicable also for assessing liquidity among municipalities.

\section{Discussion - limitation of the research results}

According to Otrusinová \& Kubíčková (2011), the current ratio is most frequently used in the business environment, though it refers the least to the true need to pay off liabilities. Based on the implemented study, it was confirmed that the current ratio is used also by municipalities, especially for the needs of the Ministry of Finance.

A certain degree of limitation is that some authors try to apply the policies for the liquidity of the private entities on the municipal accounting. On the contrary, however, a totally different method of financial management is employed in state institutions as a result of the different nature of incomes. The recommended value for private entities of the current ratio is in the interval 1.5 to 2.5. (Knapková et al., 2017,). The recommended value of the quick ratio is determined within a range from (0.7) 1.0 to 1.5. According to Kraftová (2002, p. 116), the quick ratio refers to a quick test of the financial health - the so-called Quick Test (Q-test). Once the value of the quick ratio falls under 1, the danger of insolvency is indicated. In contrast, when this ratio is higher than 1 , an inefficient binding of funds in cash and receivables is signalled.

The cash position ratio has a recommended value in the range of (0.1) 0.2 to 0.5 (0.7), following the sector. For municipal companies, this value may be higher, since it indicates the need for controlling the measure of appreciation of unused funds (Kraftová, 2002, p. 115). The ideal value of this ratio for municipal companies is around 1 . For the cash position ratio in the case of municipalities, the emphasis is primarily placed on equality between funds for payments and the needs for payments to be made. Kraftová (2002, p. 115) states that as for a healthy company 
money should represent around $20 \%$ of the value of liabilities, and therefore the cash position ratio should be around the value of 0.2 .

The problem of liquidity ratios is correctly defining the numerator and denominator of the fraction. Liquidity ratios can have a varying accuracy according to what liquidity an item has that is entered into the numerator and denominator. In terms of interpretation, this concerns a value quantified to a certain moment, in which incompatibility may occur in terms of the time structure of the second item, which is typical for municipalities due to the transfer relationships and budgetary rules. A limitation for liquidity management for municipalities is the principle of a cash base for budgets, the binding of specific funds over the budget period in extra-budgetary funds, as well as frequent changes to rules of public finance management.

Further limitations arise from the fact that liquidity measures quantities relatively independent of one another; it may be influenced by specific operations at the close of the year, and it displays the immediate situation, i.e. the status to the closing day, and not development of the payment ability over the course of the period. In the accounting of municipalities, specific items substantially influence liquidity, e.g. flow transfers, specific subsidies, clearing relationships with the state budget, and advances from transfers that are subject to the financial settlement, all of which influence liquidity values to the closing day. For this reason, it is most advantageous for managing operating cash flow to perform a calculation of the cash position ratio several times per year and use a ratio modified according to specific needs of the given municipality. In terms of municipalities, it is very important to assess the very moment of the receipt of funds and to define what is actually counted among funds available for payment. In light of the multi-source financing typical for all municipalities, liquidity ratios may indicate very different values over the course of the year in relation to transfer policy and tax deadlines. During liquidity management, this concerns having sufficient resources to pay liabilities by the right date, on time and in a corresponding form, regardless of how these aspects are termed as liquidity.

The outcomes and findings achieved by this research are to certain extent in line with another research done by Abazieva et al. (2015), who states that the liquidity management mechanisms are not used frequently enough in the budgets of the Russian Federation and municipalities. Based on controlled interviews and the statistical evaluation of accounting data, it was revealed that the use of liquidity in financial management of municipalities in the Czech Republic is low, and we may also state that based on the research, the mean values of all liquidity ratios for municipalities are higher than recommended for business organizations. Based on testing this hypothesis, however, the rejection of the zero hypothesis was not proven, so we can state that the recommended values of individual basic degrees of liquidity can be used generally for all organizations. Nevertheless, for the public non-profit sector, it is always necessary to consider which items of working capital to include in the ratio.

Many questions thus arise in this area. The competitiveness of a municipal organization is questionable since municipal organizations provide public services and do not compete on the market as other business entities.

The paper analyses the management of liquidity behaviour of Czech local municipal governments with particular attention to the liquidity constraints imposed by balanced-budget rules. 
It is true that municipalities have a totally different way of financial management in the state institutions caused by the different nature of incomes they receive. The outcomes and findings achieved by this research are to certain extent in line with another research realized by Borge \& Tovmo (2009): local governments with good fiscal conditions are more forward looking than others. The overall assessment is that the existing behaviour reflects liquidity constraints imposed by balanced-budget rules.

At present, efficient ways are being sought out of how to manage public administration and the allocation of public resources. The presented discussion contributes to corporate finance theory in its narrower area concerned about municipalities model of financial management in financial liquidity with efficiency measures as the context. That context is seen by some as controversial, especially from technical point of view. This especially relates to the implementation of new methods of measuring the performance of public sector institutions. All the public administration reforms that have been undertaken are accompanied by questions regarding the efficiency of various functions of public administration.

According to Bolivar et al. (2014), the analysis of government sustainability is considered very important. Unlike the private sector, public administration institutions and other public sector organizations are disadvantaged concerning the evaluation of performance and efficiency, as they are managed primarily on a non-profit basis and therefore cannot apply the profit criterion as a performance indicator. Data on prosperity, profitability or loss is important information necessary for financial management and performance measurement, including the information on cost structure and its links to revenues. This applies even to public sector institutions, although they often do not provide paid services. Nevertheless, their performance is always being evaluated, and thus their revenues as well (in the form of various subsidies and transfers, tax revenues, etc.). In studies dealing with this issue (e.g. Gavurova et al., 2017; Shi, 2015; Belás et al., 2017; Dobeš et al., 2017), the authors come to a single conclusion that the basic processes in the area of public administration are basically the same when compared to other segments of the national economy.

\section{CONCLUSION}

In conclusion, we can concur that non-profit organizations should control their liquidity according to the general rules, but we cannot agree that the general rules are applicable to municipalities. For municipalities, it is most advantageous to use the quick ratio and cash position ratio, since these two indicators can be best-modified to the particular needs of the given organization. Each municipality can therefore determine the mutual relationships among components of short-term assets and short-term liabilities according to their own conditions and limitations, e.g. when handling specific and flow transfers, money in funds, or tax income and expenses. A greater problem among municipalities, however, may be operational liquidity management and the cash flow of individual projects.

The paper attempts to contribute to ascertaining the level of use of liquidity instruments in the municipal sphere. As with every research, this one has certain limitations, i.e. the questionnaire survey was implemented based on controlled interviews, which are always linked to a certain level of subjectivity. Only municipalities with a high population were included in the study, and 
their contributory organizations were not included. The inclusion of contributory organizations and smaller municipalities, which are the majority, would have improved the accuracy of the analyses performed.

The role of further research will be to provide an empirical study which will discuss the values of liquidity in the municipal sphere in another EU country. Future research should concentrate on more detailed analyses of the similarities and differences among the methodologies and evaluative strategies regarding the resulting impacts on public finance.

\section{References}

1. Abazieva, K. G., Goncharova, S. N., Maslennikova, L. P., \& Stratan, D. I. (2015). Methods of Management of Public Financial Resources. Mediterranean Journal of Social Sciences, 6 (3), 60-70. https://doi.org/10.5901/mjss.2015.v6n3p60

2. Androniceanu, A., \& Popescu, C. R. (2017). An inclusive model for an effective development of the renewable energies public sector. Administration and Public Management, 28 (1), 81-96.

3. Astrini, N. (2015). Local Government Performance Measurement: Developing Indicators Based on IWA 4. Public Organization Review, 15 (3), 365-381. https://doi.org/10.1007/s11115014-0276-9

4. Becerra, A. D., Androniceanu, A., \& Georgescu, I. (2016). Sensitivity and vulnerability of European countries in time of crisis based on a new approach to data clustering and curvilinear analysis. Administratie si Management Public, 27 (1), 46-61.

5. Belás, J., Mišanková, M., Schönfeld, J., \& Gavurova, B. (2017). Credit risk management: financial safety and sustainability aspects. Journal of Security and Sustainability Issues, 7 (1), 79-93. https://doi.org/10.9770/jssi.2017.7.1(7)

6. Bolívar, M. P. R., Galera, A. N., Muñoz, L. A., \& Subirés, D. L. (2014). Factors Influencing Local Government Financial Sustainability: An Empirical Study. Lex Localis-Journal of Local Self-Government, 12 (1), 31-54. https://doi.org/10.4335/12.1.31-54

7. Borge, L. E., \& Tovmo, P. (2009): Myopic or Constrained by Balanced-Budget Rules? The Intertemporal Spending Behavior of Norwegian Local Governmentsl FinanzArchiv. Public Finance Analysis, 65 (2), 200-219. https://doi.org/10.1628/001522109X466518

8. Checherita-Westphal, C., Klemm, A., \& Viefers, P. (2016). Governments' payment discipline: The macroeconomic impact of public payment delays and arrears. Journal of Macroeconomics, 47 (B), 147-165. doi: dx.doi.org/10.1016/j.jmacro.2015.12.003.

9. Chovancova, B., \& Hudcovsky, J. (2016). Return-risk profile of Slovak pension funds. Administratie si Management Public, 27, 96-106.

10. Collignon, S. (2012). Fiscal Policy Rules and the Sustainability of Public Debt in Europe. International Economic Review, 53 (2), 539-567. https://doi.org/10.1111/j.14682354.2012.00691.x

11. Czech Statistical Office (2016). Regionální statistiky. Retrieved February 2, 2016 from http:// www.czso.cz/csu/czso/regiony_mesta_obce_souhrn. 
12. Dittrichova, J. (2009). Asset Management of Municipatilies. In. Hradecke ekonomické dny 2009, díl 1: Ekonomicky rozvoj a management regionu. Economic development and regional management, 74-78.

13. Dobeš K., Kot S., Kramoliš J., \& Sopková G. (2017). The Perception of Governmental Support in the Context of Competitiveness of SMEs in the Czech Republic. Journal of Competitiveness, 9 (3), 34-50. https://doi.org/10.7441/joc.2017.03.03

14. Drew, J,. \& Campbell, N. (2016). Autopsy of Municipal Failure: The Case of Central Darling Shire. Australasian Journal of Regional Studies, 22 (1), 79-102.

15. Gavurova B., Tkacova A., \& Tucek D. (2017). Determinants of Public Fund's Savings Formation via public Procurement Process. Administration and Public Management, 28 (1), $25-44$.

16. Gavurova, B., \& Korony, S. (2016). Efficiency of day surgery in Slovak regions during the years 2009-2014. Economic Annals-XXI, 159 (5-6), 80-84.

17. Grizzle, C., Sloan, M., \& Kim, M. (2015). Financial factors that influence the size of nonprofit operating reserves. Journal of Public Budgeting, Accounting and Financial Management, 27 (1), 67-97.

18. Hansen, S. W., Houlberg, K., \& Pedersen, L. H. (2014). Do Municipal Mergers Improve Fiscal Outcomes?. Scandinavian Political Studies, 37 (2), 196-214. https://doi.org/10.1111/14679477.12020

19. Janoušková, J., \& Sobotovičová, Š. (2017). Property tax in the regions of the Czech Republic. E+M: Ekonomie a management, 20 (4), 120-134. https://doi.org/10.15240/ tul/001/2017-4-009

20. Jegers M. (2011). Financing constraints in nonprofit organisations: A Tirolean approach. Journal of Corporate Finance, 17 (3), 640-648.

21. Knápková, A., Pavelková, D., Remeš, D., \& Šteker, K. (2017). Finanční analýza: komplexní prìvodce s príklady. 3. kompletně aktualizované vydání. Praha: Grada Publishing.

22. Kraftová, I. (2002). Finančni analýza municipálni firmy. Praha: C. H. Beck.

23. Lagos, R., \& Rocheteau, G. (2009). Liquidity in Asset Markets with Search Frictions. Econometrica, 77 (2), 403-426. https://doi.org/10.3982/ECTA7250

24. Michalski, G. (2016). Risk pressure and inventories levels. Influence of risk sensitivity on working capital levels. Economic Computation and Economic Cybernetics Studies and Research, 50 (1), 189-196.

25. Mohelská, H., \& Sokolová, M. (2017). Digital transparency in the public sector - case study Czech Republic. E+M: Ekonomie a management, 20 (4), 236-250. https://doi.org/10.15240/ tul/001/2017-4-016

26. Monitor. (2016). Retrieved from http://monitor.statnipokladna.cz/2016/

27. Nemec, J. (2016). In Hamernikova B. (Ed.), "Wicked problem”: Measuring efficiency - performance in the public sector. Praha 1: Newton Collas. 
28. Otrusinová, M., \& Kubíčková D. (2011). Finanční hospodareni municipálních účetnich jednotek: po novele zákona o účetnictví. Praha: C. H. Beck.

29. Papcunova, V. (2013). Evaluation of financial performance of contributory organizations under the jurisdiction of municipalities. Acta Regionalia et Environmentalica, 10 (1), 13-18. https://doi.org/10.2478/aree-2013-0003

30. Prentice, C. (2016). Understanding Nonprofit Financial Health: Exploring the Effects of Organizational and Environmental Variables. Nonprofit and Voluntary Sector Quarterly, 45(5), 888-909. https://doi.org/10.1177/0899764015601243

31. Rauscher, S., \& Wheeler, J. (2012). The importance of working capital management for hospital profitability: Evidence from bond-issuing, not-for-profit U.S. hospitals. Health Care Management Review, 37 (4), 339-346. https://doi.org/10.1097/HMR.0b013e3182224189

32. Romolini, A., Gori, E., \& Fissi, S. (2015). Public Corporate Governance and Performance Information in Local Utilities: The Different Perceptions of Politicians and Managers. Administratie si Management Public, 25 (1), 55-77.

33. Rosen, H., \& Sappington, A. (2016). To borrow or not to borrow? An analysis of university leverage decisions. Research in Economics, 70 (1), 170-185. https://doi.org/10.1016/ j.rie.2015.10.005

34. Shi, S. (2015). Liquidity, assets and business cycles. Journal of Monetary Economics, 70 (1), 116-132. https://doi.org/10.1016/j.jmoneco.2014.10.002

35. Schwert, M. (2017). Municipal Bond Liquidity and Default Risk. The Journal of Finance, 72 (4), 1683-1722. https://doi.org/10.1111/jofi.12511

36. Szymanska, A., \& Jegers, M. (2016). Modelling Social Enterprises. Annals of Public and Cooperative Economics, 87 (4), 501-527. https://doi.org/10.1111/apce.12127

37. Upadhyay, S., Sen, B., \& Smith, D. (2015). The cash conversion cycle and profitability: A study of hospitals in the state of Washington. Journal of Health Care Finance, 41(4).

38. Vodakova, J. (2014). Performance measurement in the Czech public sector. 8th International Days of Statistics and Economics, 1606-1614.

39. Woronkowicz, J. (2016). Is Bigger Really Better?: The Effect of Nonprofit Facilities Projects on Financial Vulnerability. Nonprofit Management and Leadership, 27 (1), 79-94. https://doi.org/10.1002/nml.21209

40. Wynne, A. (2012). An Efficient Technical Solution or an Ideologically Contested Approach - the Balance sheet for business style accrual accounting in the public sector. International Journal On Government Financial Management, 12 (1), https://doi.org/10.2139/ssrn.2019530

41. Yu-Thompson, Y. Lu-Andrews, R., \& Fu, L. (2015). Liquidity and corporate governance: evidence from family firms. Review of Accounting and Finance, 15 (2), 144-173. https://doi. org/10.1108/RAF-03-2015-0039 
Contact information

Ing. Milana Otrusinova, Ph.D.

Tomas Bata University in Zlin

Faculty of Management and Economics

Czech Republic

E-mail:otrusinova@utb.cz.

ORCID: 0000-0001-9128-777X

Ing. Alena Kulleova

Tomas Bata University in Zlin

Faculty of Management and Economics

Czech Republic

E-mail:kulleova@utb.cr.

ORCID: 0000-0002-0149-8491 